\title{
PALYNOLOGICAL DATA ON A HOLOCENE PEAT DEPOSIT IN TROPICAL BRASIL: PRELIMINARY PALEOCLIMATIC AND PALEOECOLOGICAL INTERPRETATIONS
}

\author{
May Christine MODENESI \\ Therezinha S. MELHEM
}

\begin{abstract}
RESUMO
A evolução das vertentes do planalto de Campos do Jordão durante o Pleistoceno é documentada por três gerações de anfiteatros de erosão, que refletem uma seqüência de importantes movimentos de massa relacionados a fases de incisão de caráter tectônico e a flutuações climáticas - provavelmente na transição para os climas mais secos contemporâneos das duas últimas glaciações do hemisfério norte. No Holoceno, processos com menor ação erosiva teriam depositado os colúvios das vertentes, evidenciando diminuição do ritmo de levantamento do planalto e da intensidade das flutuações do clima de montanha. $\mathrm{O}$ acentuado contraste ambiental criado pelo aparecimento dos anfiteatros teria condicionado a distribuição da vegetação e a organização do mosaico mata-campo.

O estudo palinológico de um depósito turfoso de base de anfiteatro permitiu detectar mudanças na cobertura vegetal do planalto durante o Holoceno Superior. Variações das associações vegetais das matas e dos campos seriam explicadas pelo ajustamento das formações vegetais a variações das condições de temperatura e umidade. Estas modificações refletiriam a transição dos climas mais quentes e provavelmente mais secos do Holoceno Médio para o clima atual do planalto, caracterizado por temperaturas mais baixas e por distribuição mais homogênea das chuvas.
\end{abstract}

\section{ABSTRACT}

In the Campos do Jordão Plateau, the slopes show at least three generations of erosion amphitheaters. Amphitheater genesis would reflect a succession of deep mass movements related to Pleistocene incision phases of tectonic character and to climatic fluctuations - probably during the transition to drier climates contemporaneous of the last two glaciations of the northern hemisphere. In the Holocene, climatic fluctuations and uplift rhythm lessened; colluvia on slopes point to less intense erosive phenomena. Pleistocene evolution of slopes, resulting in marked environmental contrasts, determined the distribution of vegetation on slopes and the organization of the forest-grassland mosaic. Palynology of a Holocene peat deposit shows changes in the plateau vegetation from 4,170 years BP, probably linked to climatic variations. Adjustment of plant formations to variable temperature and moisture conditions would have modified the composition of forest and grassland communities. These modifications would reflect the transition from warmer and perhaps drier Middle Holocene climates to the present climate of the plateau, characterized by lower temperatures and more homogeneous rainfall distribution.

\section{INTRODUCTION}

The Campos do Jordão Plateau (Figure 1), is the summit surface of Southeastern Brasil (AB' SABER \& BERNARDES, 1958), a block mountain uplifted over $2,000 \mathrm{~m}$ above sea level by an Oligocene deformation, further enhanced during the Pliocene (ALMEIDA, 1976). Lower Proterozoic gneisses and migmatites as well as Upper Proterozoic granitoid rocks are the predominant lithologies. Schists, quartzites and metaconglomerates are minor occurrences (IPT, 1981). Quaternary evolution of the plateau under montane climates produced a singular tropical landscape system, the altos campos (high grasslands), contrasting with the surrounding lowlands.

At the Campos do Jordão Plateau mean annual temperatures are around $14^{\circ} \mathrm{C}$ and annual rainfall is rather variable -800 to $2,800 \mathrm{~mm}$. About $80 \%$ of the rain falls from October to March, thus defining a relatively dry period in autumn and winter. In the higher areas, next to the Mantiqueira escarpment, orographic influences cause a lowering of temperatures and an increase in rainfall; the dry season is not so well defined. 

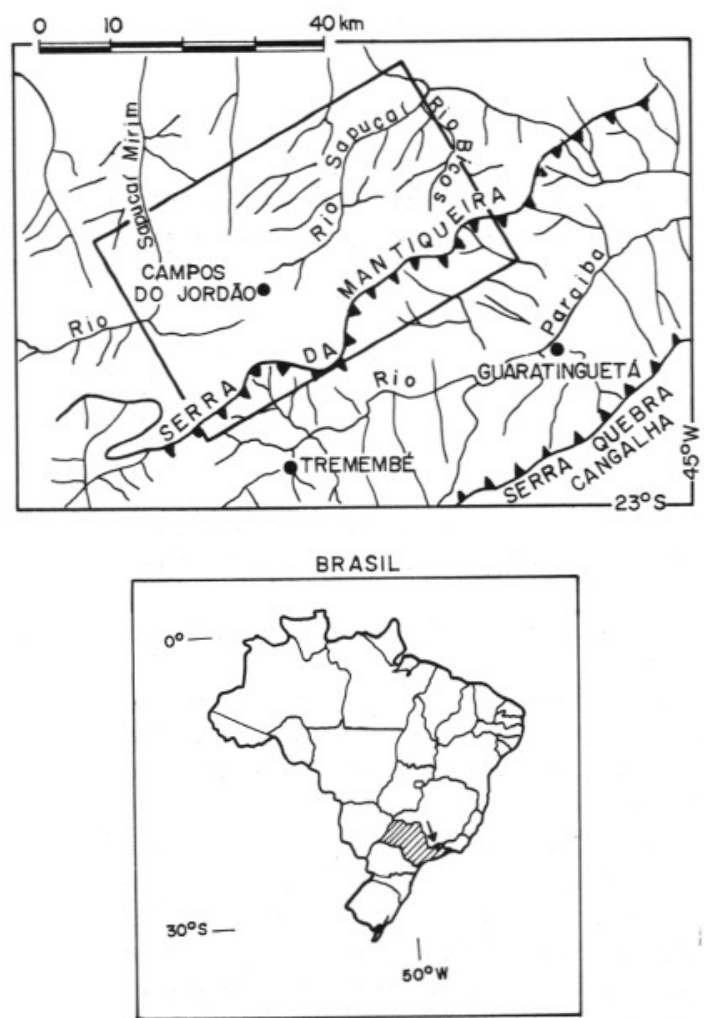

FIGURE 1 - Location of the Campos do Jordão Plateau.

The altos campos landform pattern is characterized by a sharp contrast between the gently sloping convexities of hilltops and lombas (grass-covered convex slopes) and the dissected sectors of slopes and erosion amphitheaters. Vegetation forms a typical forestgrassland mosaic, strongly linked to landforms, drainage and surficial materials. Grassland occupies hilltops and convex slopes. Forest is confined to the dissected sectors of slopes, mainly to amphitheaters where deeper soils and especially the incoherent regolith still have a supply of primary minerals (MODENESI, 1983). On the edges of the plateau and in deeply dissected areas, the altos campos mosaic is replaced by continuous forest cover.

Previous studies (MODENESI, 1984, 1988) showed that the Pleistocene evolution of altos campos slopes reflects a succession of deep mass movements (slides and slump-slides) responsible for the formation of at least three generations of erosion amphitheaters. These events would correspond to the mobilization of thick regoliths in the transition to drier climates during colder epochs of the Middle and Late Pleistocene, which were tentatively related (BIGARELLA \& AB' SABER, 1964) to the last two glaciations of the northern hemisphere. Amphitheater genesis would also reflect an increase of erosive activities related to incision phases of tectonic character.

There is evidence that morphodynamic activity in the slopes decreased during the Holocene (MODENESI, 1984, 1988): on the lower part of the lombas three colluvial levels are intercalated with dark paleosols, indicating the alternance of slope denudation episodes with phases of relative stability and pedogenesis.

One of the highest points in southeastern Brasil, the Campos do Jordão Plateau would have been exposed, during the coldest phases of Quaternary glacial epochs, to temperatures much lower than the present ones. A cooling of approximately 4 to $6^{\circ} \mathrm{C}$ is estimated for this area of South America, during the coldest phase of the last ice age (18,000 years BP) (GATES, 1976). These considerations, plus the results of geomorphological analysis (MODENESI, i988), seem to indicate that Quaternary climatic fluctuations had a significant role in the development of the altos campos landscape. Although climatic fluctuations were probably lessened in the summit areas of Southeastern Brasil (AB'SABER, 1977, 1980), the plateau followed, at least to some extent the rhythm of regional morphogenetic evolution. An alternation of morphoclimatic systems linked to montane subtropical environmental conditions - either warm and wet or relatively dry and cold - would have been effective. The greater morphodynamic activity observed in the Pleistocene would reflect major climatic fluctuations associated to the uplift rhythm of the block (MODENESI, 1984, 1988). When altitudes were less, the morphogenetic action of Quaternary climates would have been more effective opening larger spaces of resistasy (ERHART, 1955), along a trend not too different from that of the neighbouring lowlands. Later climatic changes resulting from upheaval and decrease in uplift rhythm probably lessened the intensity of erosive phenomena in the summit areas, allowing for longer biostasy phases (ERHART, 1955).

Erosion amphitheaters would have provided conditions suitable to the expansion of forests on the slopes (MODENESI, 1980, 1983). The marked environmental contrast between amphitheaters and lombas probably accounts for the mosaic pattern of vegetation. Conditioned by the evolution of slopes, this mosaic probably remained unchanged throughout the Late Pleistocene and the Holocene (MODENESI, 1988). The adjustment of the vegetation to changes in temperature and humidity would have been reflected by changes in the distribution and extent of grassland and forest communities. In colder and drier episodes of the Late Pleistocene, when Araucaria presumably occurred in the 
plateau (AB'SABER, 1977), subtropical montane forests possibly occupied valleys and erosion amphitheaters, alternating spatially with the open vegetation - probably of a steppe type on the stony soils of hilltops and lombas.

Through geomorphic considerations and pollen analysis of peaty sediments found at the base of the more recent amphitheaters we attempt to detect changes in the Holocene vegetation and climatic conditions. The present results have led to a first set of paleoclimatic and paleoecological interpretations which are probably valid for other summit areas of southeastern Brasil.

\section{PRESENT VEGETATION}

In the Campos do Jordão Plateau, the typical forest-grassland mosaic presents sharp boundaries, with no transitional areas. Araucaria and Podocarpus forests, thick and rich in epiphytes and lianas, occupy valleys and amphitheaters. Podocarpus is denser in the wet floodplain areas (várzea). Broad-leaved forests occur in association with Araucaria, mainly in altitudes of 1,400-1,600m (SIEBERT et al., 1975). In more humid slopes, approximately between 1,600 and 2,000 m, a broad-leaved forest without Araucaria occurs. Denser and lower broad-leaved communities occupy the top of the southeastern escarpment of the plateau; this vegetation consti- tutes an unique type of forest related to the everpresent mist and to the relatively high humidity.

There are three types of grasslands in the plateau: campos limpos ("clean", open grasslands) essentially covered by herbaceous vegetation; campos sujos ("dirty", mixed grasslands) with herbs, dwarf shrubs, shrubs, and isolated stunted trees, occupying larger areas, mainly on the drier slopes; campos de altitude (montane grasslands), above $1,800 \mathrm{~m}$, which are similar to the vegetation of other summit areas of southeastern Brasil and classified as related to the subparamos of the Andes (SIEBERT et al., 1975).

Homogeneous formations of Pteridophyta commonly appear in degraded grassland areas or on steep slopes. Extensive artificial coniferous forests (exotic species of Pinus) cover hilltops and lombas previously covered by grass. In the small peat basins at the bottom of erosion amphitheaters prevail Eriocaulaceae (Eriocaulum cf. kuntii and Paepalanthus planifolius), Compositae, Melastomataceae, Cyperaceae, Umbelliferae, Pteridophyta (Blechnum) and Bryophyta (Sphagnum recurvum and $S$. nemoreum).

The fact that elements from the Andean flora and from the flora of southernmost South America were identified in the Mantiqueira (RAMBO, 1953 and BRADE, 1956), together with elements from the xerophilous flora and from Central

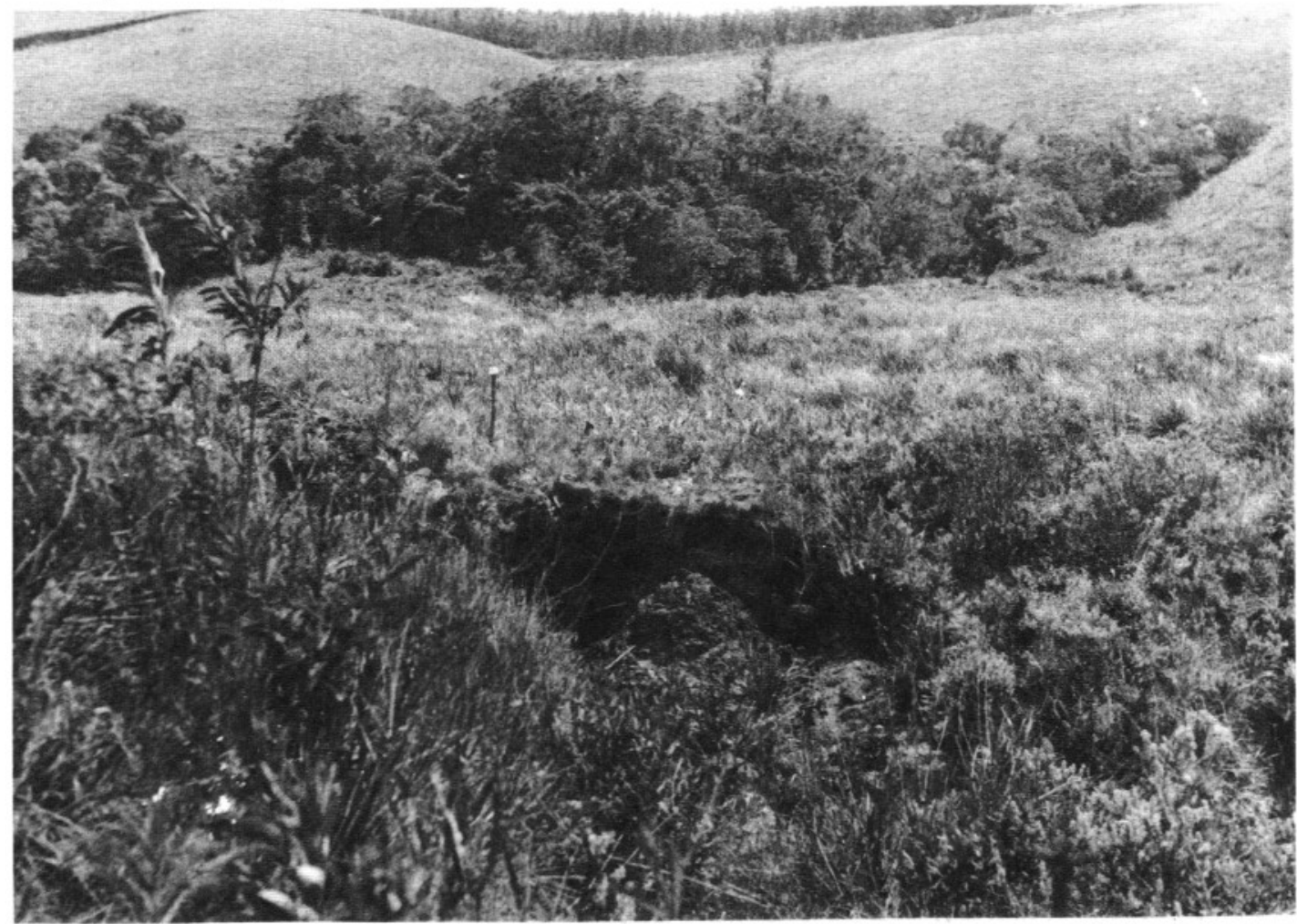

PHOTO 1 - Peat deposit at the bottom of an erosion amphitheater in the "altos campos". 


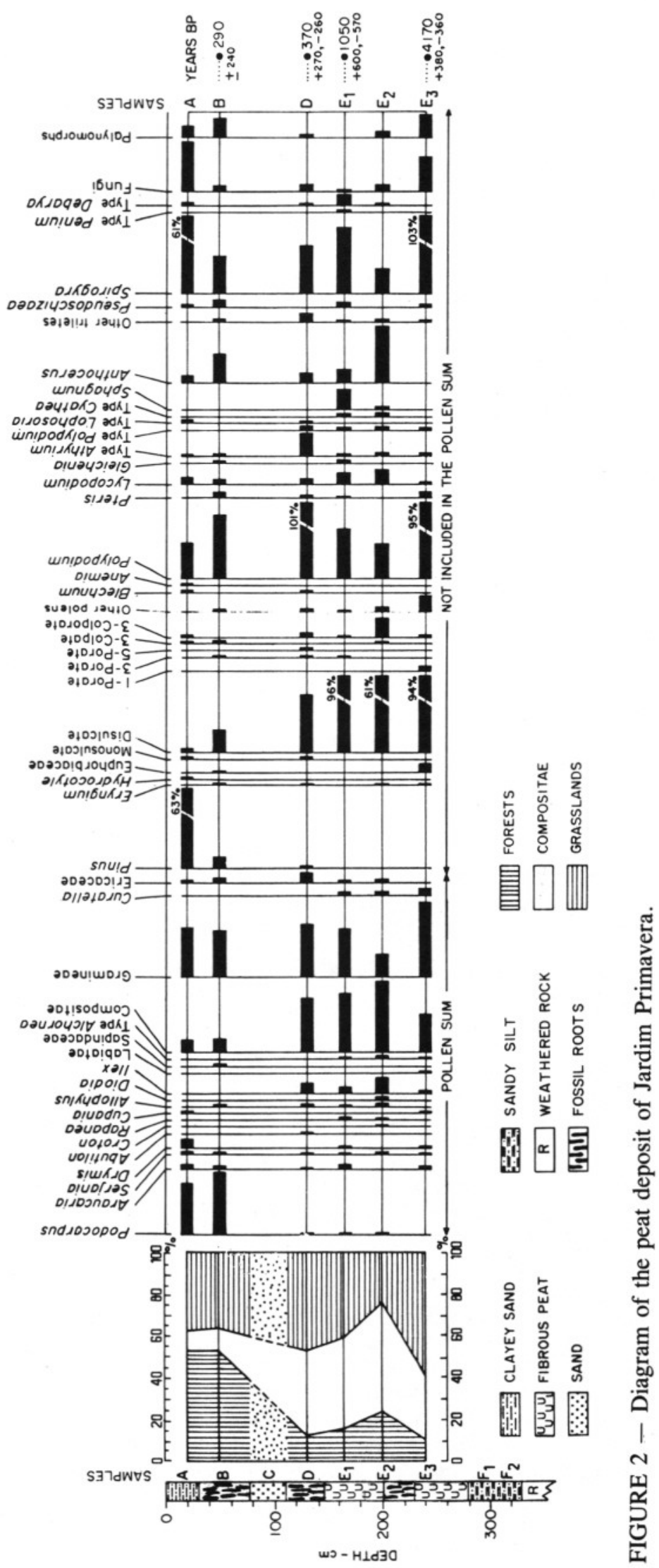


Brasil, stresses the importance of the region within the phytogeographic framework of southeastern Brasil (AZEVEDO, 1965). These elements probably entered the area during Quaternary climatic fluctuations. The succession of Quaternary climates might also be responsible for the spatial distribution of different types of plateau vegetation and, according to PAUWELLS (1941), for the expansion of forest over grassland inherited from previous drier climates. MODENESI (1980), based on an analysis of the relationships between landforms, surficial materials, degree of weathering and vegetation, came to the same conclusions.

\section{STUDY SITE AND MATERIALS}

The study site is a tropical peat-bog (stratigraphic column in Figure 2) - acid peat with an important allochthonous mineral fraction - commonly found on tops of southeastern Brazilian block mountains. It fills one of the small hydromorphic depressions at the bottom of the more recent erosion amphitheaters (Photo 1). 13 to $14 \mathrm{~m}$ above the present floodplain. Two units of acid peat (ph between 4 and 5), separated by a coarse sand laver (c, $75 / 110 \mathrm{~cm}$ ), lie over silty materials from bedrock weathering $(f, 280 / 330 \mathrm{~cm})$. The lowermost $130 \mathrm{~cm}$ of the peat $(e, 150 / 280 \mathrm{~cm})$ are constituted of silty sands with $13 \%$ of organic matter, intercalated with coarser or finer materials; this layer is here subdivided according only to color. At the top of the lower unit $(d, 110 / 150 \mathrm{~cm})$ occur black sandy silts with $55 \%$ of organic matter. The upper unit $(b$, $35-75 \mathrm{~cm}$ ) shows black silty clay with $14 \%$ of organic matter. The whole sequence is covered by $35 \mathrm{~cm}$ of yellowish-brown soil (a) developed on relatively coarse material, in sharp contrast with the finer and darker material of the peat itself. Fossil roots of Eriocaulaceae and partially decayed plant remains are present in the peat layers, especially in the darker and more humified ones $\left(b, d, e_{2}\right)$ which shows a fibrous structure.

\section{METHODS}

Samples were taken from a $330 \mathrm{~cm}$ pit wall, near the center of the peat deposit. Sample $a$ represents sediments collected at a depth of $20 \mathrm{~cm}$. Processed samples initially weighted $50 \mathrm{~g}$. Coarse mineral particles were removed by repeated sieving and decanting. Unwanted organic components were removed by potassium hydroxide treatment followed by oxidation with hydrogen peroxide and potassium chlorate. Due to the presence of an important mineral fraction, gravity separation was made with zinc chloride of specific gravity 2.0. After preparation, the residue was mounted in glycerin jelly; the slides were sealed with paraffin.
Four samples were collected for radiocarbon age determinations. The samples were dated at the Centre de Bondy-ORSTOM-France, through the Paleoclimas intertropicais agreement between $\mathrm{CNPq}-\mathrm{Brasil}$ and ORSTOM-France, under the supervision of Dr. Marc Fournier. Loss of some of the original samples made necessary renewed sampling for age determination, samples being collected at a point $20 \mathrm{~m}$ from the previous site. The materials dated at Bondy correspond to the middle of layers $b$ (Bondy 491) and $d$ (Bondy 484) and to the top (Bondy 483) and base (Bondy 492) of layer $e$.

\section{CONSTRUCTION OF DIAGRAMS}

Five hundred grains per sample were counted. In some cases, as the number of grains of the pollen sum was small (layers $d, e_{1}, e_{3}$ ), additional counts were necessary, so as to reach a minimum of 150 grains of the pollen sum. Out of the 50 recognized pollen morphological types, it was possible to identify 7 at the species, 18 at the generic, and 7 at the family level. Results were expressed in percentages and, in order to show the main vegetational changes, presented in a classical diagram, according to FAEGRI \& IVERSEN (1975). The composite diagram (Figure 2) shows, from left to right, an outline of the analyzed section, the general cumulative diagram and a resolved diagram showing the frequencies of each palynomorph. For the interpretation of diagrams, surveys of the flora and ecological data on the regional vegetation (BRADE, 1942 and 1956; AZEVEDO, 1962; SIEBERT et al., 1975; RIZZINI, 1979 and JOLY, 1983) were taken into account, as well as direct field observations. Pollen analysis of surficial sediments (a) provided some data on recent deposition.

The pollen sum (Figure 2) was based on the total of tree, shrub and herb pollen from the regional vegetation. It consists of three groups:

1. elements from the forest: Podocarpus, Araucaria, Serjania, Drymis, Abutilon, Croton, Rapanea, Cupania, Allophylus, Diodia, Ilex, Labiatae, Sapindaceae, Alchornea type.

2. elements from grasslands: Gramineae, Curatella, Ericaceae (Gaultheria and Leucothoe).

\section{Compositae.}

Pollen types presumed to be derived from the local vegetation are excluded from the pollen sum. This is the case of Hydrocotyle and Eryngium, species from forests and grasslands which also occur in the peat. Common in the pollen spectrum of sediments, some pteridophytes are typical of the wet subtropical forest, but may also 
occur in bogs (BRADE, 1942), on steep slopes, or in degraded grasslands (SIEBERT et al., 1975). Two genera of Ericaceae (Gaultheria and Leucothoe) were included in the pollen sum, as they are typical of the plateau grasslands and have not been listed in any of the floral surveys of the region.

The frequencies of elements not included in the pollen sum were calculated as percentages of this sum. Elements which are commom in the present vegetation or preserved in the peat as macrofossils are not always represented in the pollen spectra of sediments. Sphagnum, Araucaria and Cyperaceae are underrepresented, whilst some genera such as Pinus (a result of afforestation practices) and Podocarpus are overrepresented. Although absent from the pollen spectra, Eriocaulaceae are commom in the present vegetation (Eriocaulum and Paepalanthus) and were identified in the sediments by their fossil roots.

\section{INTERPRETATION OF THE DIAGRAM}

The most frequent palynomorphs belong to plants of the peat bog community, whose composition seems to change according to depth. In samples $e_{-3}$ and $e_{2}$ pollen grains from aquatic plants prevail. Pteridophyte spores, as well as cysts and spores from algae, are less frequent. In layers $e_{2}, d$ and $b$, the total of Pteridophyta and Bryophyta spores is always higher than that of aquatic plant pollen plus cysts and algal spores. In the upper layer $(a)$, algal reproductive elements are the main palynomorphs closely followed by spores of Pteridophyta and Fungi. Sample $c$ is barren and probably corresponds to a phase of more active slope erosion.

As the general diagram shows (left-hand side of Figure 2), the sharp increase in forest pollen, observed between $d$ and $b$, reflects a decrease in Compositae rather than a relative decrease of grassland pollen. From $e_{2}$ to $d$ the steady decrease of forest pollen is followed by an increase of grassland pollen percentages due to a significant decrease in Compositae. Between $e_{3}$ and $e_{2}$, the increase of forest pollen corresponds to a decrease of grassland pollen. The spectra of the topmost layer (b) of the deposit and that of the surface sample $(a)$ are very similar. In both samples, percentages of forest pollen are higher than those of grass pollen, and Compositae values are the lowest of the profile.

Individual curves for each genus, family and morphological type, both included in and excluded from the pollen sum, are represented in the resolved diagram (right-hand side of Figure 2). They complement the general diagram.
A comparision between the floral inventory of Campos do Jordão and the pollen spectra of sediments shows that only a small number of elements from the regional flora - which is very diversified - occur in the sediments. On the other hand, all the taxa present in the sediments belong either to local or to regional vegetation, with the exception of Curatella, which is not included in any regional inventory. Curatella is a very tolerant species, being one of the first cerrado species to appear and one of the last to disappear. In the lower layers (samples $e_{3}, e_{2}$ and $e_{l}$ ) of the peat deposit, pollen composition is richer; 10 to 12 of the 18 morphological types included in the pollen sum are present. In contrast, there are 9 types in sample $d$ and only 8 in samples $b$ and $a$. The greater frequency variations occur in forest elements. In the four lower peat layers $\left(e_{3}\right.$ through $\left.d\right)$, Abutilon, Croton, Cupania and Diodia are the rarest elements, and Allophylus, Serjania and Ilex the most frequent ones; Serjania and Ilex occur in all samples. Ilex is the most abundant element of the broad-leaved forest. Araucaria pollen has similar frequencies, except in $e_{2}$ where it does not show. Of the elements of the broad-leaved forest, Serjania, Drymis, Cupania, Allophylus and Sapindaceae are confined to samples $b$ or $a$. Drymis and Cupania only occur in the surficial layer $(a)$, and $\mathrm{Al}$ lophylus at the top of the peaty sequence $(b)$. The most significant change, reflected in the general diagram by a dislocation of the forest element curve, is the sudden increase of Podocarpus absent in the lowermost layer - from layer $d$ upward.

In the lower part of the diagram the increase in forest pollen corresponds to an increase in the number of pollen types and, in $e_{2}$, to maximum values of Allophylus, Diodia, Ilex and Alchornea type. The frequency of grassland elements varies between 38 and $60 \%$ of the pollen total. Percentages of grass pollen are generally high, except for $e_{2}$. Low percentages of Curatella occur only in the three lower layers. Small amounts of Ericaceae pollen grains are present throughout the profile, except for the bottom layer $\left(e_{3}\right)$.

The lower part of the general diagram $\left(e_{3}\right.$ through $d$ ) shows that the relationship between forest and Compositae frequencies is direct an increase in forest pollen corresponds to an increase in Compositae and vice versa. The relationship between forest and grassland pollens is inverse. In the upper part (samples $d$ through $a$ ) the relationship between forest pollen and Compositae pollen is inverse - an increase in forest pollen corresponds to a decrease in Compositae pollen. The frequency of Gramineae is practically the same throughout. 
The sudden decrease in Pinus percentages observed under the surface sediments may be explained by its condition as anthropogenic vegetation. On the other hand, the presence of Pinus pollen at the top of the peat deposit $(b)$ and again at the uppermost layer of the lower unit $(d)$, would probably be explained (since special precautions were taken against contamination, in the field or in the laboratory) by the vertical movement of pollen grains within sediments, a possibility to be considered (MOORE \& WEBB, 1978) in the first stages of peat formation. Friable and porous surface sediments would favour water percolation and the washing of pollen grains down from the surface to the peat upper layer $(b)$. Some grains might go right through layer $b$ - which is more recent and not well compacted - and the underlying coarse sand lens $(c)$, reaching the peaty layer $(d)$.

\section{RADIOCARBON DATING OF PEAT LAYERS}

The results of radiocarbon age determinations are the following:

$$
\begin{aligned}
& \text { Sample Number } \\
& \text { C.J.1.2 - Bondy } 491 \\
& \text { C.J.1.4 - Bondy } 484 \\
& \text { C.J.1.5 - Bondy } 483 \\
& \text { C.J.2.2 - Bondy } 492
\end{aligned}
$$

Depth

Samples for radiocarbon age determinations were taken in a profile, $20 \mathrm{~m}$ distand from the original site, which showed differences in the thickness of the topmost layer $a(30 \mathrm{~cm}$ thicker) and of layers $b, c$ and $d$ (approximately $10 \mathrm{~cm}$ thinner).

\section{PALEOCLIMATIC AND PALEOECOLOGICAL INTERPRETATION}

It is known that in tropical areas, floristic diversity and lack of data on pollen rain and plant ecology represent limiting factors on the interpretation of pollen records. The presence of certain elements from the local flora - which were not included in the pollen sum - provided some ecological information. Scarcity of Pteridophyta and Bryophyta spores and abundance of aquatic pollen grains would indicate the persistence of highly hydromorphic or even partially lacrustine conditions during the deposition of layers $e_{3}$ and $e_{1}$. On the other hand, dominance of Pteridophyta and Bryophita spores in $e_{2}, d$ and $b$ would define drier environments. These observations seem to be confirmed by the higher degree of humification of samples $e_{2}, d$ and $b$, since dark and highly humified peats would result from drier slow growing communities (FAEGRI \& IVERSEN, 1975).

Presence of spores of Zygnemataceae and Spirogyra in the sediments is not a good environmental indicator as they have a wide ecological tolerance.

$\begin{array}{cc}\text { Layer } & \text { Age } \\ & \text { Yr BP } \\ b & 290 \pm 240 \\ d & 370+270-260 \\ e_{1} & 1.050+600-570 \\ e_{3} & 4.170+380-360\end{array}$

The peat-deposit would have evolved from a partially lacustrine phase $\left(e_{3}, 4,170 \mathrm{BP}\right)$ to drier environments. Succession of wet and drier environments was probably related to water-level fluctuations due to aggradation of the hydromorphic depression and/or climatic factors (MODENESI, 1988).

Podocarpus and Pinus are always well represented in the pollen spectra of sediments, due to their greater productivity and preservation, whereas Eriocaulaceae pollen - less resistant - is absent. Some under-represented elements come from entomophilous plants such as Croton, $\mathrm{Cu}$ pania and Serjania. The most common taxa in the pollen sum are Gramineae, Compositae and Ilex in the lower part of the diagram, and Podocarpus, Drymis, Compositae and Gramineae in the upper one. Planted Pinus is a major element of the surficial layer. Changes in the forest-grassland relationship observed in the two upper layers seem to result from the significant increase in Podocarpus and decrease in Compositae. The occurrence of a greater number of pollen types in deeper layers, mainly those of the broad-leaved forest, reflects a wider diversification of forest association and contrasts with the relative homogeneity observed in the upper layers $(b$ and $a)$. The parallelism between the frequencies of forest and Compositae pollen grains, an well as the inverse Compositae-Gramineae relationship, seems to indicate the dominance of forest Compositae, at least in the lower part of the peat deposit. Should this be true, forest vari- 
ation should not have been as strongly marked as shown in the general diagram.

On the other hand, analysis of regional flora suggests that Compositae would be related more to the broad-leaved than to the Araucaria and Podocarpus forest; SIEBERT et al. (1975) and RIZZINI (1979) do not list Compositae in this association, and HUECK (1972) refers to them as secondary components of the herbaceous stratum. The probable link between Compositae and broad-leaved forest and the over-representation of Podocarpus in the upper layers would indicate a greater relative significance of forests in the lower part of the diagram and, consequently, a lesser fluctuation in the pollen curve of this plant community. Thus the evidence suggests that, rather than a questionable increase in forest dominance, there was a change in composition. The only considerable drop in percentage of grassland community elements $(23 \%)$ occurs in $\mathrm{e}_{2}$. This would indicate the persistence of a mixed grassland-forest vegetation with spatial relationship similar to the present ones during the last 4,170 years, in the whole period of peat formation. It may be concluded that in spite of the fact that the vegetation mosaic of the plateau did not undergo major changes during this period, the composition of forest communities underwent changes. The previous broad-leaved forest, represented by a higher number of species, was probably replaced from 370 BP by a more homogeneous one, with Podocarpus. Such changes - contemporaneous with the deposition of the coarse sand layer (c) that separates the lower peat unit from the upper one - would reflect climatic fluctuations: warmer conditions would have been followed by colder climates similar to the present one. The presence of Curatella in the lower part of a peat deposit seems to indicate that in the Campos do Jordão Plateau increase in temperature was followed by rainfall decrease and increasing rainfall seasonality. A drier and warm- er climate would have characterized the summits of the plateau in Middle Holocene times. Temperature changes seem to follow the trend observed in the tropical Andes (VAN der HAMMEN, 1974, 1989) where Middle Holocene temperatures were 1 to $e 2^{\circ}$ higher than today's. Further associations with changes of rainfall affecting tropical South America are difficult. It should be remembered that the summit of the plateau, facing east humid winds, is wetter than the adjacent lowlands due to the prevalence of orographic rains.

The palynological analysis indicates that adjustment of vegetation to variable temperature and humidity conditions seems to be reflected mainly by changes in plant communities of forests and grasslands. Thus, from $4,170 \mathrm{BP}$ to $1,050 \mathrm{BP}$ heterogeneous subtropical species-rich forests probably coexisted with grassland vegetation including Curatella, a genus which is typical of the cerrados. After 1,050 BP and especially 370 years BP a more homogeneous and richer-inPodocarpus forest probably replaced the previous community; Curatella seems to have vanished from the altos campos.

Variations in plant communities of the Campos do Jordão Plateau would reflect the transition to present climatic conditions, which are characterized by decrease in temperature and a more homogeneous rainfall distribution. This hypothesis agrees with the interpretation of geomorphic data and suggests, as proposed by MODENESI (1988), that even at the summits of the Campos do Jordão Plateau, slight climatic fluctuations were active during the Holocene.

\section{ACKNOWLEDGEMENTS}

This research was partially supported by the Fundação de Amparo à Pesquisa do Estado de São Paulo (FAPESP). We wish to thank Paulo Emílio Vanzolini for revision of the English text.

\section{REFERENCES}

AB'SABER. A.N. 1977 Espaços ocupados pela expansão dos climas secos na América do Sul por ocasião dos períodos glaciais quaternários. Paleoclimas, (3), 19p.

1980 Razões da retomada parcial de semi-aridez holocênica, por ocasião do “otimum climaticum". Interfacies, (8), 6p.

\& BERNARDES, N. 1958 Vale do Paraíba, Serra da Mantiqueira e arredores de São Paulo. XVIII Congr. Intern. Geogr. Rio de Janeiro, Guia de Excursões (4), 303p. Rio de Janeiro.
ALMEIDA, F.F.M. 1976 The System of Continental Rifts Bordering the Santos Basin. In: "Continental Margins of Atlantic Type". São Paulo, Oct. 1975. Anais Acad. Bras. Ci., (48):15-26.

AZEVEDO, L.G. 1962 Tipos de vegetação do sul de Minas e Campos da Mantiqueira. Anais Acad. Bras. Ci., 34(2):225-234.

1965 Contribuição à delimitação dos tipos de vegetação do Estado de São Paulo - Região de Campos do Jordão. Arquivos de Botânica do Est. de São Paulo, Nova Série 4(1):9-21. 
BIGARELLA, J.J. \& AB'SABER, A.N. 1964 Paläogeographische und Paläoklimatische Aspekte des Känozoikums in Sudbrasilien. Zeitschr. Geomorph., 8(3):286-312.

BRADE. A.C. 1942 A composição da Flora Pteridófita do Itatiaia. Rodriguésia, 6(15).

BRADE. A.C. 1956 A Flora do Parque Nacional do Itatiaia. Bol. Parq. Nac. Itatiaia, (5):5-85.

ERHART, H. 1955 Biostasie et rhéxistasie: equise d'une théorie sur le rôle de la pedogénèse en tant que phénomène géologique. Centre Recherches Scientifiques Académie des Sciences, 241:1.218-1.220.

FAEGRI, K. \& IVERSEN, J. 1975 Textbook of Pollen Analysis. Blackwell Scient. Public., 295p. Copenhagen.

GATES, W.L. 1976 Modeling the ice-age climate. Science, 191(4.232):1.138-1.143.

HUECK, K. 1972 Florestas da América do Sul. Edit. Univ. Brasília e Edit. Polígono S.A., 466p. São Paulo.

IPT - INSTITUTO DE PESQUISAS TECNOLÓGICAS DO ESTADO DE SÃO PAULO 1981 Mapa geológico do Estado de São Paulo - Escala 1:500.000.

JOLY. A.B. 1983 Botânica - Introdução à Taxonomia Vegetal. Cia. Editora Nacional, 777p., 6 ${ }^{\text {a }}$ edição. São Paulo.

MODENESI, M.C. 1980 Intemperismo e morfogênese no Planalto de Campos do Jordão, São Paulo. Rev. Bras. Geoc., 10(3):213-225.

1983 Weathering and Morphogenesis in a Tropical Plateau. Catena. 10(3):237-251.
MODENESI, M.C. 1984 Evolução Quaternária de uma montanha tropical: o planalto de Campos do Jordão, SP. Revista do Instituto Geológico, 5(1/2):7-13. 1988 Significado dos depósitos correlativos quaternários em Campos do Jordão - São Paulo: implicações paleoclimáticas e paleoecológicas. Boletim do Instituto Geológico, (7), 155p.

MOORE, P.D. \& WEBB, J.A. 1978 An illustrated guide to pollen analysis. Hodder and Stroughton. "Biological Science Texts", 133p. London.

PAUWELS, G. 1941 Algumas notas sobre a distribuição do campo e da mata no sul do país e a fixidez do limite que os separa. Rev. Bras. Geogr., 3(3):155-158.

RAMBO, B. 1953 História da flora do Planalto Riograndense. An. Bot. Herb. Barbosa Rodrigues (Itajaí), 5(5):185-232.

RIZZINI, C.T. 1979 Tratado de Fitogeografia do Brasil. Aspectos sociológicos e florísticos vol. 2, Ed. HUCITEC e EDUSP, 374p. São Paulo.

SIEBERT, P. et al. 1975 Plano de Manejo do Parque Estadual de Campos do Jordão. Bol. Técn. do Instituto Florestal, (19), 148p. e Atlas.

VAN der HAMMEN, T. 1974 The Pleistocene changes of vegetation and climate in tropical South America, Journ. Biogeogr., $1: 3-26$.

1989 Paleoecology of the neotropics: an overview of the state of affairs. Bol. Inst. Geoc. - USP. Publicação Especial, v.8, p. 35-55. 